国際ロボット展 2009

\title{
世界標準を目指したロボットセル生産用ハンドモジュール群 とマニュアル作業激減知能モジュール群の開発と検証
}

Demonstration at IREX2009

Development and Validation to Create New Global Standards of the End Effector Modules for the Robot Control Cell Production and the Intelligent Modules for Dramatic Reduction of Manual Operations

\section{1. は じめに}

今回 IDEC は, 国際ロボット展 2009 の NEDO のブース に次世代ロボット知能化技術開発プロジェクトの作業知能 (生産分野) の開発としてIDEC が取り組んでいる研究成果 を広く世間に公表できる恵まれた機会を与えられた. IDEC は,「ロボット制御セル生産システム」を世界に先駆けて実 稼動させ，高性能高信頼性を有する産業用スイッチや産業 用リレーの組立生産を拡大し, 累計 4,000 万個にも及ぶ生 産実績を挙げてきており，2005 年第一回ものづくり日本大 賞優秀賞受賞の栄誉を受け, この生産分野のパイオニアと 広く認知された存在となっている [1] [2]. 生産分野で大き な期待が寄せられているロボット制御セル生産システムの 課題としてティーチング時間の削減とチョコ停（本格的な 故障ではなく, 一時的なトラブルのために設備が停止した り空転したりする状態）からの自動復帰を実現する知能モ ジュール群の開発を目的として「ロボットセル生産用知能 ハンドモジュール群とマニュアル作業激减知能モジュール 群の開発と検証」として研究開発に取り組んでいる [3] [4]. そのなかで, 展示会で公表した二つの実証デモの内容につ いて述べる。

\section{RT コンポーネントの有効性実証デモ}

次世代ロボット知能化技術開発プロジェクトでは, RT コ ンポーネント（以後, RTC) を広く世間に普及することが 重要な取り組みとなっている。 その一環として RTC を採用 することで簡単に仕様追加・機種変更ができることを実証 した，具体的には，図 1 に示したようにRTCを接続する ことで通常動作（決められた位置に置かれた四つのブロッ クをロボットハンドで一度に把持し，ブロックを並び替え

原稿受付 2010 年 3 月 26 日

キーワード : Robot, Robothand, Gripper, End - effector, Senjyukannon

* $\bar{T}$ 532-8550 大阪市淀川区西宮原 1-7-31

*Yodogawa-ku, Osaka-shi, Osaka

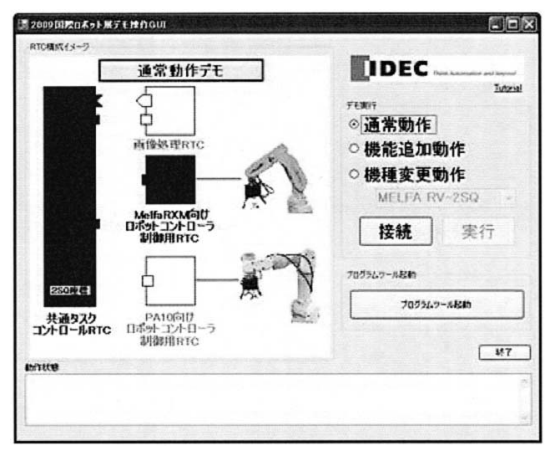

図 1 RTC による機能追加・機種変更の検証画面

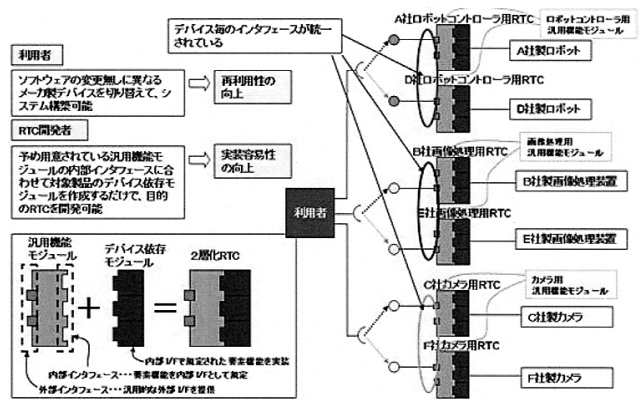

図 22 層化 RTC の内部構造

IDEC のロゴが出来上がる）から, 機能追加動作（画像処 理 RTC を追加し，バラバラに置いた四つのブロックの位 置を検出して同様に IDEC のロゴを作る), さらに, 機種 変更動作（ロボットを三菱電機製 MELFA から三菱重工製 PA10 に同一プログラムを使用して機種変更し, 機能追加 動作を実現する）を動作させた。この同一プログラムで違 うロボットを同様に動作させることは，ロボットの標準化 を実現するために重要な技術であり，それを実現するため に2 層化 RTC と呼ぶ内部構造を考案した，その内部構造 を図 2 に示す．1 層目の汎用機能モジュールで沉用的な外部 インタフェースを規定し， 2 層目のデバイス依存モジュール でロボットごとの違いを吸収する構造となっている。汎用 


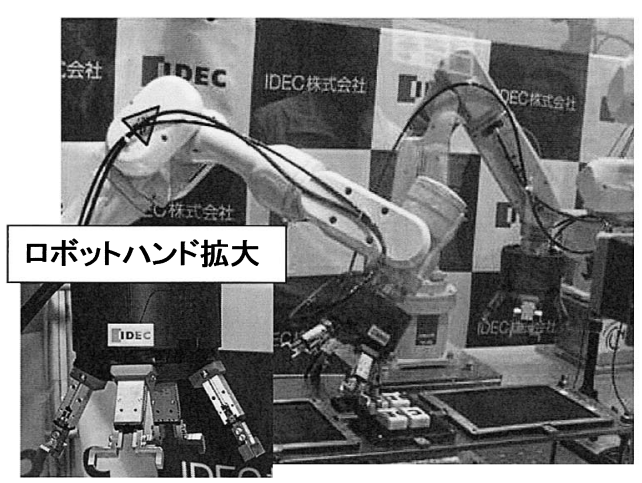

図 3 RTC の有効性実証デモ風景

機能モジュールを再利用し, 違うロボットのデバイス依存 モジュールを設計するだけで, 新たなロボットの制御 RTC のバリエーション追加が簡単にでき, 実装容易性の向上が 実現できる [3]，その実証デモの模様を示した写真が図 3 で ある。実証デモで使用した IDEC が開発した四つのブロッ クを同時に把持できるマルチロボットハンドは, 来場者に 好評を博し，ロボットハンドの事業化への大きな手応えを 感じた.

\section{3. ティーチング時間削減実証デモ}

研究の求められる成果としてティーチング時間の削減が 重要な要素であるが, その研究成果としてティーチング補 助治具である三角錐の形をした発光物である LED 指示棒を 持って，生産現場でティーチング座標を指し示すことによ り, ステレオカメラによる画像処理にて LED 指示棒の先端 の位置でティーチング座標を検出し, 三角錐の 3 色のうちの 赤色平面の方向でハンドの指先が把持する方向も合わせて 一度にティーチングできることを実現している，この実証デ モの RTC 知能モジュール群の構成は, 「Sense」+「Plan」 $+\lceil$ Act」の 3 部構成になっており,「Sense」の RTC とし て “LED 指示棒画像処理 RTC”, そして, 「Plan」の RTC として “教示支援・座標補正コントロール RTC”, さらに, 「Act」の RTC として “MELFA ロボットコントローラ制 御 RTC”を開発し，これらの RTC を接続することにより デモの実演を行った。その技術の見せ方として，図 4 に示 したように電撃ビリビリ棒ゲームを模した通路を作り，そ の通路を通過できるように会場にて LED 指示棒を使って 実際にティーチングを行い，そのティーチングデータを元 にロボットに電撃ビリビリ棒ゲームを実行させる実証デモ を行った、ロボットがゲームに挑戦する娛楽性もあり, 来場

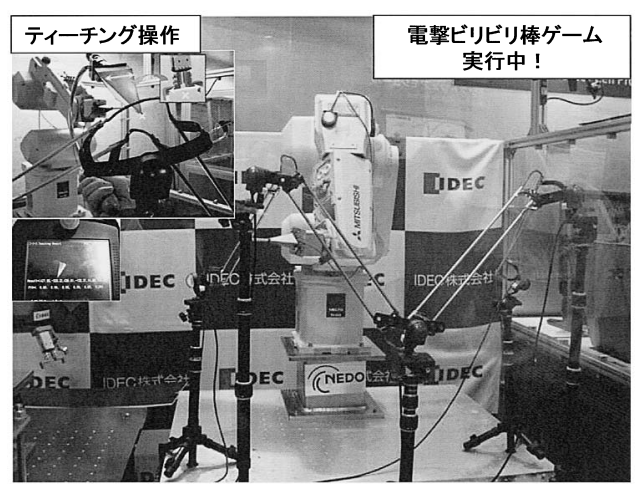

図 4 LED 指示棒による一発ティーチングの実証デモ風景

者に喜んでいただけ，ティーチングが簡単にできるメリッ トも感じてもらえた。

\section{4. 今後の 展 開}

今後は, これら実証デモで公表した研究成果を $\mathrm{RT}$ ミド ルウェア化された知能化ロボットハンドとして製品化・事業 化し，生産分野でのロボット制御セル生産システムのス夕 ンダードの地位構築を目指し, 研究に邁進する所存である.

\section{参 考 文 献}

[1] 藤田俊弘, 樋口伸夫, 菅野祥人, 林弘之 : “多品種変量生産に最適な 千手観音モデルによるロボット制御セル生産システム”, 日本ロボッ ト工業会「ロボット」, no.173, pp.7-14, 2006.

[2] T. Fujita, N. Higuchi, Y. Sugano, H. Hayashi, K. Ida, T. Takagi, M. Nishino, W. Tokumoto, H. Yonezawa and T. Nishiki: "Robot Control Cell Production System of Senju (thousandhanded) Kannon Model that Demonstrated Optimality to the Multi-product Production in Varying Volumes for Eight Years," IEEE CASE2008, pp.478-485, 2008.

[3] 米澤浩, 菅井祐平, 濱田航一, 飯田勝久: “汎用機能モジュールとデバイ ス依存モジュールを組み合わせた 2 層化 RTC による再利用性，実装容 易性の向上”, 第 27 回日本ロボット学会学術講演会予稿集 CD-ROM, AC1D2-01, 2009.

[4] 米澤浩, 濱田航一, 飯田勝久：“ロボット制御セル生産システムにお けるチョコ停からの自動復帰手法”, 第 27 回日本ロボット学会学術講 演会予稿集 CD-ROM, AC1D2-02, 2009.

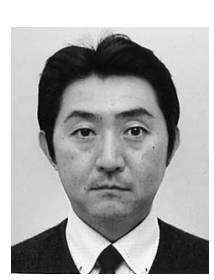

米澤 浩 (Hiroshi Yonezawa)

電子制御設計技術者として多くの製品開発に 携わり、ロボットのティーチングペンダント の標準化を主導し，その成果として「今年の ロボット」大賞 2007 優秀賞を受賞した．現在 は, ロボット制御セル生産システムの研究に 取り組み, 経済産業省の委託研究「次世代口 ボット知能化技術開発プロジェクト」の主任研究員に従事. 